\title{
Slope variation and population structure of tree species from different ecological groups in South Brazil
}

\author{
EDMILSON BIANCHINI, CRISTINA C. GARCIA, JOSÉ A. PIMENTA and JOSÉ M.D. TOREZAN \\ Departamento de Biologia Animal e Vegetal, Centro de Ciências Biológicas, Universidade Estadual de Londrina \\ Caixa Postal 6001, 86051-970 Londrina, PR, Brasil \\ Manuscript received on December 17, 2008; accepted for publication on May 5, 2010
}

\begin{abstract}
Size structure and spatial arrangement of 13 abundant tree species were determined in a riparian forest fragment in Paraná State, South Brazil $\left(23^{\circ} 16^{\prime} \mathrm{S}\right.$ and $\left.51^{\circ} 01^{\prime} \mathrm{W}\right)$. The studied species were Aspidosperma polyneuron Müll. Arg., Astronium graveolens Jacq. and Gallesia integrifolia (Spreng) Harms (emergent species); Alseis floribunda Schott, Ruprechtia laxiflora Meisn. and Bougainvillea spectabilis Willd. (shade-intolerant canopy species); Machaerium paraguariense Hassl, Myroxylum peruiferum L. and Chrysophyllum gonocarpum (Mart. \& Eichler ex Miq.) Engl. (shade-tolerant canopy species); Sorocea bonplandii (Baill.) Bürger, Trichilia casaretti C. Dc, Trichilia catigua A. Juss. and Actinostemon concolor (Spreng.) Müll. Arg. (understory small trees species). Height and diameter structures and basal area of species were analyzed. Spatial patterns and slope correlation were analyzed by Moran's I spatial autocorrelation coefficient and partial Mantel test, respectively. The emergent and small understory species showed the highest and the lowest variations in height, diameter and basal area. Size distribution differed among emergent species and also among canopy shade-intolerant species. The spatial pattern ranged among species in all groups, except in understory small tree species. The slope was correlated with spatial pattern for A. polyneuron, A. graveolens, A. floribunda, R. laxiflora, M. peruiferum and T. casaretti. The results indicated that most species occurred in specific places, suggesting that niche differentiation can be an important factor in structuring the tree community.
\end{abstract}

Key words: diameter structure, ecological groups, forest fragment, seasonal semideciduous forest, spatial pattern.

\section{INTRODUCTION}

Plants had different requirements related to seed germination, seedling emergence and survival and recruitment to higher size classes (Messaoud and Houle 2006, Tsujino and Yumoto 2007). Soil water availability, soil fertility and light are among these requirements (Messaoud and Houle 2006). Because the resources related to these requirements are heterogeneously distributed in the environment (Bianchini et al. 2001, Messaoud and Houle 2006), there is often a high spatial heterogeneity in microsites suitable for tree seedling establishment (Houle 1992).

Microsites heterogeneity often correlates with spa-

Correspondence to: Edmilson Bianchini

E-mail: bianchi@uel.br tial distributions of tropical trees, suggesting that ecological sorting caused by niche differentiation may be important in structuring tropical forest tree communities (Svenning 1999, Harms et al. 2001, Russo et al. 2005). In environmentally biased spatial distributions, tree species should show performance (mortality and growth rates) differences when growing in different habitats. Russo et al. (2005) observed species performance variation among soil types in a Bornean rain forest and concluded that performance-based ecological sorting among soils was evident.

Contrasting habitat associations and resource availability modify vital rates during regeneration, so that realized vital rates range widely among species (Wright et al. 2003). As size distribution is a synthesis of the 
vital rates (Kelly et al. 2001), it should range among species in a site. Wright et al. (2003) presented the size distribution for the 73 tree species from Barro Colorado, Panama. The authors found several kinds of size distributions, such as the one with many large individuals and a long tail of relatively rare, small individuals (negative skeweness) characterizing light-demanding species, and the one with many small individuals and a long tail of relatively rare, large individuals (positive skeweness) characterizing shade-tolerant species. The authors concluded that most species has intermediate light requirements and lifestyles.

It has been demonstrated that topography and related edaphic characteristics affect the tree species distribution (Botrel et al. 2002, Rodrigues et al. 2007, Tsujino and Yumoto 2007). Pioneer species may be more abundant in steeper than lower slope sites, because sloppy terrains have more frequent and larger gaps resulting from landslips (Russo et al. 2005). We studied a sloppy terrain and we therefore expected to find differences in spatial pattern distribution of abundant species from different ecological groups.

Wishing to contribute to the knowledge of tree species ecology in Atlantic Forest fragments, the aim of this work was to determine the size and spatial structures of some of the abundant species from different ecological groups of a riparian forest fragment. The main asked questions were: 1) Do size and spatial structures differ among species groups? 2) Is the slope related to species spatial distribution? As this area shows well-lit conditions (J.A. Costa, unpublished data), we expected that emergent and shade-intolerant canopy species showed predominance of large individuals (negative skeweness), random spatial pattern and their distribution not associated with the slope. Contrastingly, the shade-tolerant canopy and understory small species showed predominance of small individuals (positive skeweness), clumped spatial pattern in shady places and their distribution associated with the slope.

\section{METHODS}

\section{STUdy AREA AND SAMPLING}

The 100 ha of seasonal semideciduous forest fragment are situated on a private property called "Fazenda Doralice" (hereafter FD), which lies on the left margin of the Tibagi River $\left(23^{\circ} 16^{\prime} \mathrm{S}\right.$ and $\left.51^{\circ} 01^{\prime} \mathrm{W}\right)$. The climate is Köppen's Cfa, with a mean annual temperature of $21.8^{\circ} \mathrm{C}$ and mean annual rainfall of $1570 \mathrm{~mm}$. The soil is fertile and has a clayish texture (Soares-Silva et al. 1992).

A phytosociological (tree community structure) study was conducted using a 1 ha $(100 \mathrm{~m} \times 100 \mathrm{~m})$ plot, subdivided into hundred $10 \mathrm{~m} \times 10 \mathrm{~m}$ subplots, and included all trees with at least $5 \mathrm{~cm}$ of stem diameter at $1.30 \mathrm{~m}$ height (Soares-Silva et al. 1992).

One side of the plot was aligned with the riverbank. The site has no flood-prone terrain, and subplots near the riverbank (up to the $4^{\text {th }}$ subplot row) have a strong slope (mean $45 \%$ ) with shallow soil and frequent rock outcrops, litter removal by surface rainwater and hillside illumination (steep slope area). The rest of the subplots lies on a gradually higher and deeper soil terrain (intermediate and gentle slope areas). The canopy seemed to be heterogeneous, ranging from $8 \mathrm{~m}$ to $12 \mathrm{~m}$ height, with few clearings but an increased winter illumination due to leaf fall (which occurs for $20-50 \%$ of the trees).

\section{Community Structure And Selection of Species}

In the phytosociological inventory, the species were arranged on the basis of importance value (IV) (Brower and Zar 1984), and we selected 13 of the 15 species with the highest IV. These species are common in seasonal semideciduous forest fragments in southern and southeastern Brazil. Using field observations and literature data (Silva and Soares-Silva 2000, Cavalheiro et al. 2002, Bianchini et al. 2003), the selected species were divided into four groups: emergent species - Aspidosperma polyneuron Müll. Arg., Astronium graveolens Jacq. and Gallesia integrifolia (Spreng) Harms; shadeintolerant canopy species - Alseis floribunda Schott, Ruprechtia laxiflora Meisn. and Bougainvillea spectabilis Willd.; shade-tolerant canopy species - Machaerium paraguariense Hassl, Myroxylum peruiferum L. and Chrysophyllum gonocarpum (Mart. \& Eichler ex Miq.) Engl.; small understory trees species - Sorocea bonplandii (Baill.) Bürger, Trichilia casaretti C. Dc, Trichilia catigua A. Juss. and Actinostemon concolor (Spreng.) Müll. Arg.

Total height and perimeter or diameter at breast height $(\mathrm{DBH})$ data from phytosociological inventory 
were used to compare the vertical structure and the basal area $\left(\mathrm{BA}=\right.$ perimeter $\left.^{2} / 4 \pi\right)$ of species and species groups. The individuals of each sampled population were distributed in nine diameter classes with $5 \mathrm{~cm}$ interval, except for the last two classes, to determine the diameter structure of each species. These criteria were considered the best to represent the sampling populations, as it did not produce empty classes and allowed to species structure comparison. We used KolmogorovSmirnov test $(\alpha \leq 0,05)$ to evaluate the differences among diameter structure of species (Siegel 1975). Although the inclusion of individuals of DBH $<5 \mathrm{~cm}$ is desirable, these data are not available due to constraints in field logistics. While this feature of the sample may limit our conclusions, several other studies have been discussing tree size structure using just higher size classes (e.g. Manabe et al. 2000, Bianchini et al. 2003, Tsujino and Yumoto 2007).

We used the number of individuals for each $10 \times$ $10 \mathrm{~m}$ subplot and subplot center coordinates to determine the spatial pattern of each species. The spatial pattern was analyzed using Moran's $I$ spatial autocorrelation coefficient (Legendre and Fortin 1989) calculated for 12 distance classes, testing the null hypothesis that the $I$ coefficient, at each distance class, is not significantly different from zero, indicating randomness (Legendre and Fortin 1989). A spatial correlogram was build based on $I$ values as a function of the distance classes, and its significance was tested using Bonferroni criterion (Oden 1984).

To correlate the spatial pattern to slope, we determined the subplot slope from a 1:100 topographic map. The relationship between the spatial patterns of individuals of each species and slope was estimated with partial Mantel tests (Legendre and Fortin 1989). P-levels for these tests were determined by a permutation procedure (from 1000 permutations). The autocorrelation analyses and partial Mantel tests were performed with Passage Software (Rosenberg 2001).

\section{RESULTS}

\section{Size STRUCTURE}

For A. polyneuron and A. graveolens populations, only $2 \%$ and $8 \%$ of the individuals reached a height over
$20 \mathrm{~m}$, respectively, in which the mean height of $A$. graveolens was greater than $A$. polyneuron (Table I). These species showed a positive skeweness diameter distribution (negative exponential curve) with nearly $70 \%$ of their individuals in the $1^{\text {st }}$ diameter class (Fig. 1A), but with no individuals in the $>25-50 \mathrm{~cm}$ range for $A$. polyneuron and $>35-50 \mathrm{~cm}$ range for $A$. graveolens. Three individuals of $A$. polyneuron with more than $74 \mathrm{~cm}$ diameter led to a higher mean and standard deviation values than A. graveolens, although this species showed a higher median (Table I).

The G. integrifolia population was composed of large individuals (Table I), with $24 \%$ of them being over $20 \mathrm{~m}$ height. This species showed lower height variation than other two emergent species (Table I). G. integrifolia showed individuals in all diameter classes, with no prevalence in any of them (Fig. 1A). As for height, this species showed greater diameter mean and median values and lower diameter variation than other emergent species (Table I).

The height data of shade-intolerant canopy species were very similar, whereas these data for shade-tolerant canopy species were discrepant (Table I). In this group, M. paraguariense showed greater variation than other species did.

Diameter distribution patterns differed among shade-intolerant canopy species (Fig. 1B). R. laxiflora showed a negative exponential distribution shape, with most of its individuals $(57.5 \%)$ in the first diameter class. This species showed higher diameter variation than other species of this group. A. floribunda showed an almost bimodal pattern, with an increased number of individuals in the first (32\%) and $5^{\text {th }}(19 \%)$ diameter class (Fig. 1B). B. spectabilis differed from the latter species, having most of its individuals in the first two classes (Fig. 1B), while mean and median diameters suggest that $A$. floribunda population included larger individuals than $R$. laxiflora and B. spectabilis did (Table I).

The diameter distribution of shade-tolerant canopy species was similar to a negative exponential pattern (Fig. 1C). For M. paraguariense and C. gonocarpum, most individuals (nearly 55\%) belonged to the first diameter class, while $M$. peruiferum showed a similar number of individuals in the first two classes. M. peruiferum showed a higher median diameter than the other two 
TABLE I

Height, diameter and basal area data for a sample of tree species in a riparian forest fragment in Fazenda Doralice, Ibiporã, Paraná State, Brazil. H - height (m); D - diameter (cm); BA - basal area $\left(\mathrm{m}^{2} \mathrm{ha}^{-1}\right)$; $\mathrm{X}$ - mean; $\mathrm{S}$ - standard deviation; Md - median; CV - coefficient of variation (\%). Number of individuals are in parentheses in front of the species name.

\begin{tabular}{l|c|c|c|c|c|c|c|c|c}
\hline & \multicolumn{3}{|c|}{$\mathrm{H}$} & \multicolumn{4}{c|}{$\mathrm{D}$} \\
\cline { 2 - 8 } & $\mathrm{X}$ & $\mathrm{S}$ & $\mathrm{Md}$ & $\mathrm{CV}$ & $\mathrm{X}$ & $\mathrm{S}$ & $\mathrm{Md}$ & $\mathrm{CV}$ & \\
\hline Emergent trees & 10.5 & 6.7 & 7.3 & 64.4 & 17.7 & 19.4 & 9.6 & 110 & 6.41 \\
Aspidosperma polyneuron (34) & 8.1 & 5.5 & 6.5 & 67.8 & 14.2 & 20.7 & 6.4 & 146 & 1.64 \\
Astronium graveolens (52) & 9.3 & 5.8 & 7.0 & 62.3 & 11.5 & 11.1 & 7.6 & 96.4 & 1.03 \\
Gallesia integrifolia (33) & 14.7 & 7.5 & 14.0 & 50.8 & 31.0 & 22.2 & 25.1 & 71.8 & 3.73 \\
\hline Shade-intolerant canopy trees & 8.4 & 3.3 & 7.5 & 39 & 16.2 & 12.5 & 11.5 & 77.2 & 3.39 \\
Alseis floribunda (37) & 8.2 & 3.3 & 7.5 & 40 & 20.6 & 14.2 & 16.7 & 69 & 1.81 \\
Ruprechtia laxiflora (40) & 8.2 & 3.2 & 7.5 & 39 & 13.1 & 11.6 & 9.0 & 88 & 0.95 \\
Bouganvillea spectabilis (26) & 8.8 & 3.5 & 8.0 & 40 & 14.8 & 9.72 & 12.1 & 65.9 & 0.63 \\
\hline Shade-tolerant canopy trees & 9.8 & 5.4 & 8.5 & 55.3 & 14.9 & 13.4 & 10.5 & 90 & 2.60 \\
Machaerium paraguariense (29) & 9.4 & 5.6 & 7.3 & 59.8 & 15.6 & 17.5 & 8.6 & 112 & 1.22 \\
Myroxylum peruiferum (26) & 12.8 & 6.2 & 11.5 & 48.2 & 16.7 & 12.5 & 12.4 & 75.3 & 0.88 \\
Chrysophyllum gonocarpum (29) & 7.4 & 2.6 & 7.0 & 35.3 & 12.3 & 8.5 & 8.6 & 69.2 & 0.50 \\
\hline Small understory trees & 5.9 & 1.7 & 5.9 & 29.4 & 8.1 & 3.9 & 7.0 & 48.2 & 2.41 \\
Sorocea bonplandii (134) & 5.8 & 1.9 & 5.5 & 32.9 & 7.4 & 2.4 & 6.8 & 33.1 & 0.63 \\
Trichilia casaretti (117) & 6.3 & 1.7 & 6.0 & 27.2 & 10.0 & 5.2 & 9.2 & 51.6 & 1.17 \\
Thichilia catigua (43) & 5.9 & 1.6 & 5.5 & 26.8 & 6.8 & 1.8 & 6.1 & 26.3 & 0.17 \\
Actinostemon concolor (82) & 5.5 & 1.4 & 5.2 & 25.9 & 7.4 & 3.7 & 6.4 & 50.4 & 0.44 \\
\hline
\end{tabular}

species in this group did (Table I). However, M. paraguariense presented higher diameter variation than other species (Table I).

Height data were quite similar among the four understory small tree species (Table I). T. casaretti and $S$. bonplandii had individuals reaching $13 \mathrm{~m}$ height, in spite of their classification as understory trees. Species of this group had a diameter distribution with a negative exponential shape, with most individuals $(60 \%)$ in the first diameter class, followed by a strong reduction in the second one (Fig. 1D). Mean and median diameter data suggest that $T$. casaretti reached greater sizes and higher diameter variation than other species of this group did (Table I).

The emergent species group showed the higher variation in height and diameter, especially A. polyneuron, and higher basal area, mainly G. integrifolia, whereas the small understory trees group showed the lower variation (Table I). It should be mentioned that $A$. floribunda showed the second higher basal area among species (Table I).
Gallesia integrifolia, Alseis floribunda and Trichilia casaretti diameter structures differed (KS test, $\mathrm{p}<0,05$ ) from other species of their groups. No difference among shade-tolerance canopy species was observed. The result was complex when we considered the species all together. In general, the diameter structure of G. integrifolia differed from all species, except for $C$. gonocarpum, whereas M. paraguariense just differed from G. integrifolia and S. bonplandii.

\section{Spatial Distribution}

The spatial pattern of C. gonocarpum (correlogram globally not significant) and B. spectabilis was random in the study site (Fig. 2B, C). All other species showed spatial gradient with significant positive autocorrelation at short distances, and significant negative autocorrelation at large distances (Fig. 2). The correlogram of these species can be divided into four kinds: a) A. polyneuron and $A$. concolor presented clumps of ca. 10-20 m (Fig. 2A, D); b) six species presented clumps of ca. 10-30 m (Fig. 2); c) A. graveolens and S. bonplandii presented 

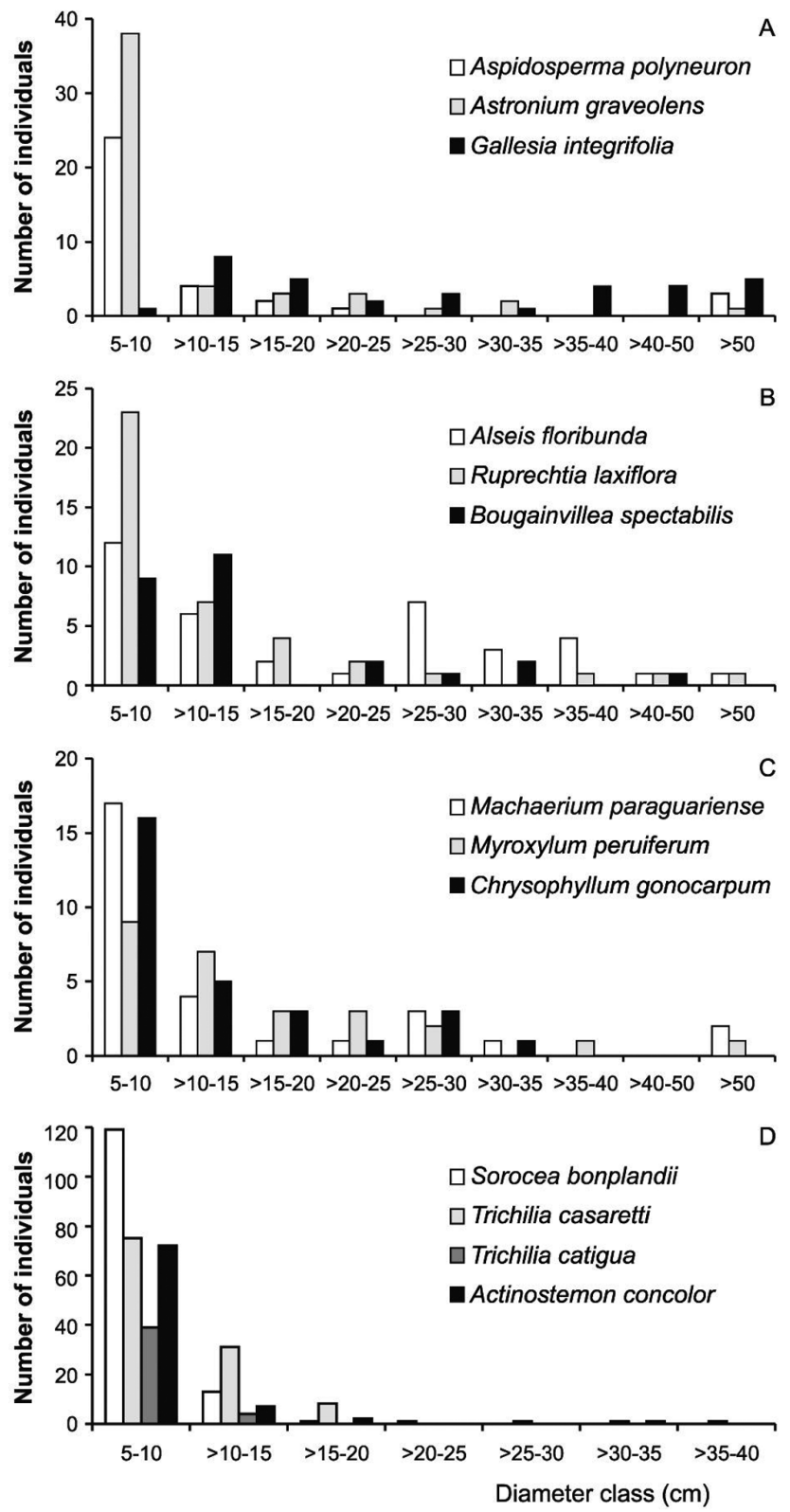

Fig. 1 - Diameter class distribution of individuals of tree species in a riparian forest fragment in Fazenda Doralice, Ibiporã, Paraná State, Brazil. A - emergent trees; B - shade-intolerant canopy trees; $\mathrm{C}$ - shade-tolerant canopy trees; D - small understory trees.

clumps of ca. 10-40 m (Fig. 2A, D); d) M. paraguariense presented clumps of ca. $50 \mathrm{~m}$ (Fig. 2C).

The spatial distribution pattern of $A$. floribunda, $A$. polyneuron, A. graveolens, M. peruiferum, $R$. laxiflora and $T$. casaretti was associated with slope (Table II). These species showed clumps at steep slope area, and A. graveolens and A. polyneuron had higher and lower size clumps, respectively.
Although the spatial pattern of other seven species was not associated with slope (Table II), G. integrifolia and $S$. bonplandii were more abundant at the gentle slope (ca. 53\%) than intermediate (ca. 24\% and 37\%) and steep slope areas (ca. 24\% and 10\%), whereas $A$. concolor and C. gonocarpum were abundant at the intermediate slope (57\% and 56\%). M. paraguariense and T. catigua occurred mainly in steep and intermediate 

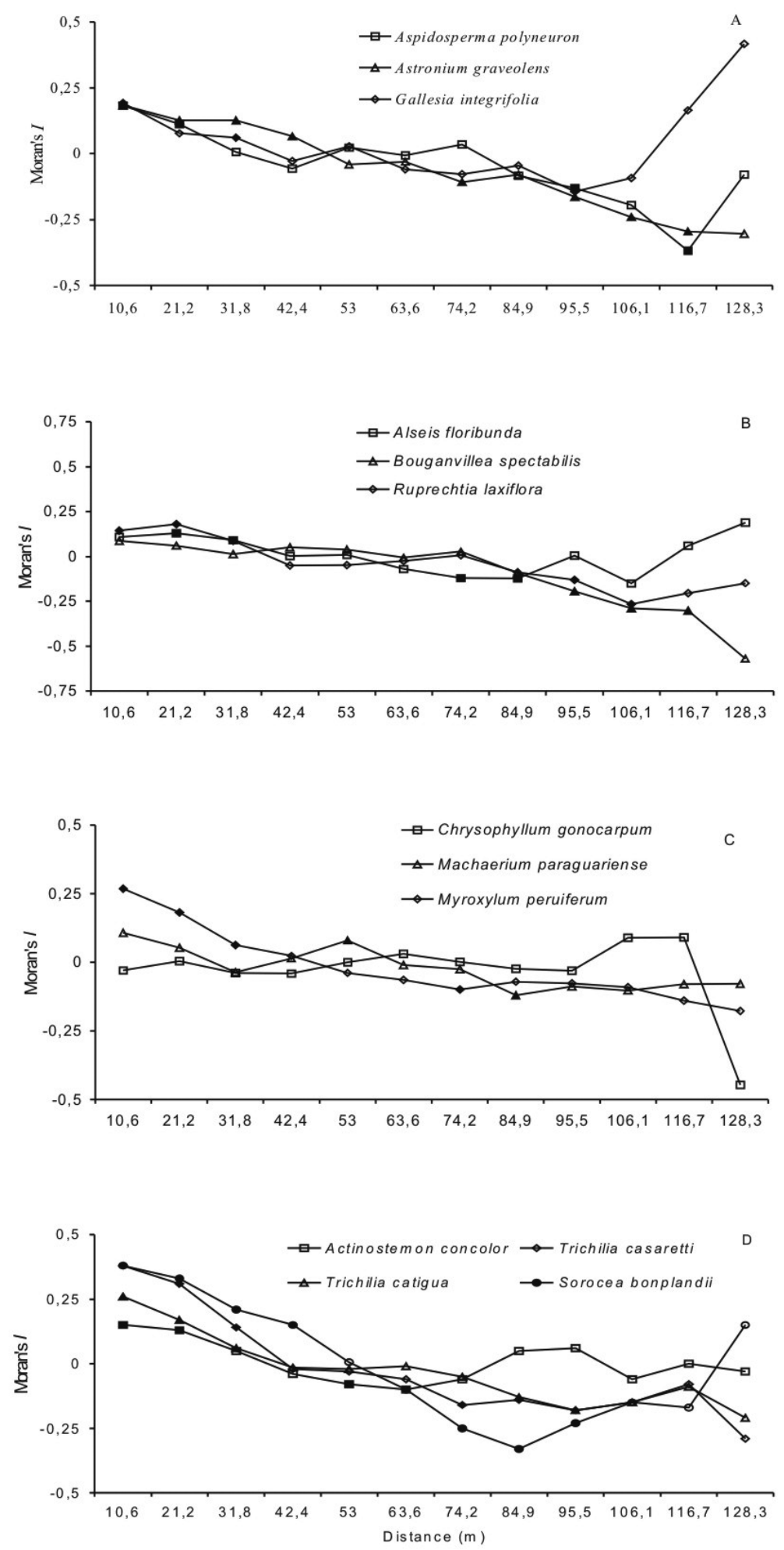

Fig. 2 - Spatial correlogram of 13 tree species density in a riparian forest fragment in Fazenda Doralice, Ibiporã, Paraná State, Brazil. A - emergent trees; B - shade-intolerant canopy trees; C - shade-tolerant canopy trees; D - small understory trees. The abscissa corresponds to the upper limit $(\mathrm{m})$ of each distance class. Black points indicate significant Moran's $I$ values at the $\alpha=5 \%$ level (for globally significant correlograms), and white points are non-significant values. 
TABLE II

Partial Mantel test for tree species density and slope in a riparian forest fragment in Fazenda Doralice, Ibiporã, Paraná State, Brazil.

\begin{tabular}{l|c|c}
\hline \multicolumn{1}{c|}{ Species } & $\mathrm{r}$ & $\mathrm{p}$ \\
\hline Actinostemon concolor & -0.03 & $>0.47$ \\
\hline Alseis floribunda & 0.21 & $<0.001$ \\
\hline Aspidosperma polyneuron & 0.12 & $<0.003$ \\
\hline Astronium graveolens & 0.11 & $<0.01$ \\
\hline Bouganvillea spectabilis & -0.07 & $>0.11$ \\
\hline Chrysophyllum gonocarpum & -0.06 & $>0.13$ \\
\hline Gallesia integrifolia & -0.01 & $>0.73$ \\
\hline Machaerium paraguariense & 0.04 & $>0.37$ \\
\hline Myroxylum peruiferum & 0.24 & $<0.0001$ \\
\hline Ruprechtia laxiflora & 0.14 & $<0.003$ \\
\hline Sorocea bonplandii & 0.06 & $>0.14$ \\
\hline Trichilia casaretti & 0.15 & $<0.0005$ \\
\hline Thichilia catigua & 0.06 & $>0.20$ \\
\hline
\end{tabular}

slope, while $B$. spectabilis was more abundant in intermediate and gentle slope.

\section{DISCUSSION}

Contrary to our expectations, the size distributions were not typical for emergent species and for shade-intolerant canopy species. All sampled populations, except $G$. integrifolia, showed a prevalence of small individuals, suggesting that they had potential to regeneration (Kellman et al. 1998, McLaren et al. 2005) and partially supporting the idea of Kellman et al. (1998) regarding the bias toward rare species when extinction occurs in fragmented habitats.

The lack of $G$. integrifolia in small diameter classes did not necessarily suggest a population decline. This kind of size distribution could be related to its shadeintolerance. Authors have often observed a mass seedling emergence on the forest floor near adult individuals, followed by their disappearance months later, and the presence of saplings of this species only in gaps and at the forest edge. Light-demanding species usually show high growth rates, which reduce the number of small individuals and increase the number of large individuals (Condit et al. 1998). Besides, saplings of these species die quickly when overtopped and shaded by another tree (Wright et al. 2003).
The current paradigm posits a dominant axis of life history variation among tree species in closed canopy forests, ranging from light-demanding pioneer species to shade-tolerant climax species (Denslow 1987). Some studies that compared size distribution of co-occurring species revealed the existence of functional groups of species with similar life histories (Poorter et al. 1996, Wright et al. 2003), confirming such paradigm. This seems to be the case of the studied seasonal semideciduous forest. The species ranged from shade-intolerant species, like $G$. integrifolia, to very shade-tolerant species, like $T$. catigua and $S$. bonplandii.

Also for spatial pattern, our expectations could not be confirmed for emergent species and for shadeintolerant canopy species. Most of the studied species showed clumped spatial pattern. This pattern is reported to be common to tropical trees (Condit et al. 2000). The clumping of individuals may be a consequence of limited dispersion, vegetative reproduction or environmental heterogeneity (Hutchings 1997). Dispersal limitation is negligible in the studied spatial scale (one ha) and the species did not show vegetative reproduction in the area. These results suggested the existence of microsites with particular light environment, soil chemical composition, and moisture that are favorable to the regeneration of these species. Niche differentiation has been reported to be important in structuring tropical forest tree communities (Svenning 1999, Harms et al. 2001).

The classification of species into groups or guilds imposes a degree of simplification that reduces information content, but reveals general patterns and facilitates predictions about forest processes (Swaine and Whitmore 1988). In each group, members share important characteristics for determining the forest structure and composition (Swaine and Whitmore 1988). However, size distribution and spatial pattern were not common between emergent species and canopy shade-intolerant ones. Species differ in their life history in different ways. The shade-tolerance degree in different life stages need to be investigated, especially in seasonal forests.

Diameter structure and spatial distribution ranged among canopy emergent species. Whereas A. polyneuron and $A$. graveolens showed several seedling and saplings in the forest, this is not observed for $G$. integrifolia (field observations). These species differ in wood den- 
sity, with a denser wood for the first two species (Carvalho 1994). Species with denser woods have slower growth rates (Wright et al. 2003), resulting in size distribution with many small individuals. A. polyneuron and A. graveolens spatial distribution showed an association with slope and had a higher density in subplots near the riverbank, a sunny and shallow soil environment. The first species is a sciophyte and a deep-soil specialist, while the second species is a heliophyte, preferring dry and rocky soils (Lorenzi 2000). In a slope terrain, canopy gaps and lateral illumination provide a sunny environment to the regeneration of $A$. graveolens, while soil accumulation that occurs in some microsites should be related to the small clumpings of $A$. polyneuron.

During the development of the North Paraná State region in the last century, G. integrifolia was empirically associated with (and used by people as an indicator of) deep and fertile soils (Lorenzi 2000), that is concordant with the results of this study, in which the species was more abundant on the gentle slope area.

The lack of individuals of $A$. polyneuron and $A$. graveolens, which are two high-valued commercial timber species (Carvalho 1994), in the diameter ranges of $25-50 \mathrm{~cm}$ and $35-50 \mathrm{~cm}$, respectively, suggests that selective logging could have taken place at the studied site in the past. Another source of evidence of human impact and selective harvesting was the low density of Euterpe edulis Mart. (Arecaceae; heart of palm), less than 2 trees.ha $^{-1}$ (Soares-Silva et al. 1992), versus over 100 trees.ha ${ }^{-1}$ in another mature forest fragment in the $50-\mathrm{km}$ range of the study site (Soares-Silva and Barroso 1992).

Among canopy shade-intolerant species, $R$. laxiflora and $A$. floribunda occurred in clumps preferably in the subplots near riverbanks. The slope and canopy heterogeneity, which provides a sunny environment, can be related to the species spatial distribution. However, R. laxiflora showed high abundance in alluvial areas in other well-conserved forest fragment of the region (Bianchini et al. 2003). Further studies need to be done with this species. A. floribunda showed bimodal size distribution suggesting alteration in resource allocation pattern when the individual reach the canopy. Ontogenetic shifts would cause multimodal size distributions, with few individuals in size classes with rapid growth and high mortality, and many individuals in size classes with slow growth and low mortality (Condit et al. 1998). Alseis blackiana provides an example to ontogenetic shifts in Barro Colorado (Dalling et al. 2001). Although B. spectabilis occurred randomly in the area, it was more common in gentle slope areas. This species was not dependent of gap because small individuals have a behavior that is similar to the one of lianas.

The spatial distribution of $C$. gonocarpum was consistent with the one observed in a floodplain site in another forest fragment of the same region (Bianchini et al. 2003). The slope-independent spatial distribution of this species suggests that it could be a microsite generalist. On the other hand, both M. peruiferum and $M$. paraguariense showed an aggregated spatial pattern, with the first species occurring preferentially in the steep slope and shallow-soil subplots near the riverbank. $M$. paraguariense did not show a relationship with slope. While M. peruiferum have been considered a typical canopy species of semideciduous Atlantic Forest elsewhere, in this study nearly one-third (27\%) of its individuals showed a height superior to the mean height of canopy species (i.e., $>12 \mathrm{~m}$ height), which is a greater proportion of the population than the one of A. polyneuron (nearly $9 \%$ of individuals over $12 \mathrm{~m}$ height).

All small understory species showed negative exponential curve and clumped spatial pattern. Bianchini et al. (2003) found the same results for understory species, including A. concolor and T. catigua, in other forest fragment of the region. The high abundance of understory species in tree communities of semideciduous Atlantic Forest in northern Paraná State (Soares-Silva and Barroso 1992, Soares-Silva et al. 1992, 1998, Bianchini et al. 2003) can contribute to the decrease of microsite heterogeneity in forests by increasing plant cover and reducing light, compensating for the canopy gaps and favoring shade-tolerant species regeneration.

Although only $T$. casaretti was associated with slope, A. concolor and S. bonplandii showed discordant spatial distribution, with the first species occurring near the riverbank (rocky and shallow soil, more gaps, sunny environment), $S$. bonplandii in the gentle slope area (with deep soil, less gaps), and A. concolor in an intermediate position on the slope. Such discordant distribution suggests that competition is avoided or mini- 
mized by small differences in shade tolerance, which is an important factor in the species coexistence (Manabe et al. 2000). The factors affecting T. catigua distribution are not clear, although it showed no relationship with slope.

Height data indicate a strong overlap among species, making the identification of strata in the forest difficult, as reported by many authors for tropical forests. Among small understory trees, only $T$. catigua showed strictly small sizes, while some individuals of $T$. casaretti and $S$. bonplandii reached the canopy layer. Canopy species, such as $C$. gonocarpum, may limit its distribution to the lower boundary of the stratum, while others, such as M. peruiferum, can have emergent trees among their individuals.

Our predictions were partially met, especially to shade tolerant species. Shade tolerance variation can explain the results for otherwise light-demanding species. Evidences of niche differentiation were found, but a study associating microhabitat to regeneration performance is need to confirm such hypothesis. In FD forest fragment, the slope explained the distribution of six of the 13 studied species, while "slope" itself can be viewed as a broad factor that encompasses many variables, such as soil depth, drainage, water retention, frequency of gaps and so on.

\section{RESUMO}

Visando contribuir para o conhecimento das estratégias de vida de espécies em fragmentos florestais, foram determinadas as estruturas de tamanho e espacial de 13 espécies arbóreas do remanescente de floresta ciliar no Estado do Paraná, no Sul do Brasil $\left(23^{\circ} 16^{\prime} \mathrm{S}\right.$ e $\left.51^{\circ} 01^{\prime} \mathrm{W}\right)$. Foram analisadas as espécies: Aspidosperma polyneuron Müll. Arg., Astronium graveolens Jacq. e Gallesia integrifolia (Spreng) Harms, (emergentes); Alseis floribunda Schott, Ruprechtia laxiflora Meisn. e Bougainvillea spectabilis Willd. (dossel, intolerantes à sombra); Machaerium paraguariense Hassl, Myroxylum peruiferum L. e Chrysophyllum gonocarpum (Mart. \& Eichler ex Miq.) Engl. (dossel, tolerantes à sombra); Sorocea bonplandii (Baill.) Bürger, Trichilia casaretti C. Dc, Trichilia catigua A. Juss. e Actinostemon concolor (Spreng.) Müll. Arg. (subosque). Analisou-se a estrutura de diâmetro de cada espécie. Para a análise do padrão espacial e correlação com a declividade foram utilizados o Índice de Autocorrelação es- pacial de Moran e o Teste Parcial de Mantel, respectivamente. Os grupos das árvores emergentes e das espécies de subosque apresentaram as maiores e as menores variações na altura e no diâmetro e maior e menor área basal, respectivamente. Diferenças nas estruturas de diâmetro foram observadas entre as espécies emergentes e entre as espécies de dossel intolerantes à sombra. $\mathrm{O}$ padrão espacial variou entre as espécies de todos os grupos, exceto as espécies de subosque tolerantes à sombra. A topografia estava relacionada com a distribuição espacial de A. polyneuron, A. graveolens, A. floribunda, R. laxiflora, $M$. peruiferum e $T$. casaretti. A análise dos resultados indicou que para cada espécie a maioria dos indivíduos ocorriam em locais específicos, sugerindo que a diferenciação de nicho pode estar relacionada à estruturação desta comunidade arbórea.

Palavras-chave: estrutura de diâmetro, grupos ecológicos, fragmento florestal, floresta estacional semidecidual, padrão espacial.

\section{REFERENCES}

Bianchini E, Pimenta JA And Santos FAM. 2001. Spatial and temporal variation in the canopy cover in a tropical semi-deciduous forest. Braz Arch Biol and Technol 44: 269-276.

Bianchini E, Popolo RS, Dias MC and Pimenta JA. 2003. Diversidade e estrutura de espécies arbóreas em área alagável do município de Londrina, Sul do Brasil. Acta Bot Bras 17: 405-419.

Botrel RT, Oliveira FilHo AT, RODRIGUES LA AND CURI N. 2002. Influência do solo e topografia sobre as variações da composição florística e estrutura da comunidade arbórea-arbustiva de uma floresta estacional semidecidual em Ingaí, MG. Rev Brasil Bot 25: 195-213.

BROWER JE AND ZAR JH. 1984. Field and laboratory methods for general ecology, $2^{\text {nd }}$ ed., Dubuque: Brown Publishers.

CARVAlho PER. 1994. Espécies florestais brasileiras: recomendações silviculturais, potencialidades e uso da madeira, Brasília: EMBRAPA/CNPF/SPI

CAVAlheiro AL, Torezan JMD AND Fadeli L. 2002. Recuperação de áreas degradadas: procurando por diversidade e funcionamento dos ecossistemas. In: MEDRI ME, Bianchini E, Shibatta AO and Pimenta JA (Eds), A bacia do rio Tibagi, Londrina, p. 213-224.

Condit R, Sukumar R, Hubbel SP and Foster RB. 1998. Predicting populations trends from size distributions: a direct test in a tropical tree community. Am Nat 152: 495-509. 
CONDit R ET AL. 2000. Spatial pattern in the distribution of tropical tree species. Science 288: 1414-1418.

Dalling JW, Winter K, NAson JD, Hubbell SP, MURAWSKI D AND HAMRICK J. 2001. The unusual lifehistory of Alseis blackiana: a shade-persistent pioneer tree: Ecology 82: 933-945.

DENSLOW JS. 1987. Tropical rainforest gaps and tree species diversity. An R Ecol Syst 18: 431-451.

Harms Ke, Condit R, Hubbell SP and Foster RB. 2001. Habitat associations of tree and shrubs in a 50-ha neotropical forest plot. J Ecol 89: 947-959.

Houle G. 1992. The reproductive ecology of Abies balsamea, Acer saccharum and Betula alleghaniensis in the Tantaré Ecological Reserve, Québec. J Ecol 80: 611-623.

Hutchings MJ. 1997. The structure of plant population. In: Crawley JM (Ed), Plant Ecology, Oxford: Blackwell Scientific Publ, p. 97-136.

Kellman M, TACKaberry R ANd RigG L. 1998. Structure and function in two tropical gallery forest communities: implications for forest connection in fragmented systems. J Appl Ecol 35: 195-206.

KELLY CK ET AL. 2001. Investigations in commonness and rarity: a comparative analysis of co-occurring, congeneric Mexican trees. Ecol Lett 4: 618-627.

LEGENDRE P AND ForTin M-J. 1989. Spatial pattern and ecological analysis. Vegetatio 80: 107-138.

LoRenZi H. 2000. Árvores brasileiras, Nova Odessa: Plantarum.

Manabe T, Nishimura N, MiUra M and Yamamoto S. 2000. Population structure and spatial patterns for tree in a temperate old-growth evergreen broad-leaved forest in Japan. Plant Ecol 151: 181-197.

MCLaren KP, McDonald MA, Hall JB And Healey JR. 2005. Predicting species response to disturbance from size class distributions of adults and saplings in a Jamaican tropical dry forest. Plant Ecol 181: 69-84.

Messaoud Y And Houle G. 2006. Spatial patterns of tree seedling establishment and their relationship to environmental variables in a cold-temperate forest of eastern North America. Plant Ecol 185: 319-331.

ODEN NL. 1984. Assessing the significance of a spatial correlogram. Geogr Anal 16: 1-16.

Poorter L, Bongers F, VAN Rompaey SARR AND KLERK M. 1996. Regeneration of canopy tree species at five sites in West African moist forest. For Ecol Manage 84: 61-69.
Rodrigues LA, CARvalho DA, Oliveira Filho AT AND CURI N. 2007. Efeitos de solos e topografia sobre a distribuição de espécies arbóreas em um fragmento de floresta estacional semidecidual, em Luminárias, MG. R Árvore 31: 25-35.

Rosenberg MS. 2001. PASSAGE - Pattern Analysis, Spatial Statistics, and Geographic Exegesis. Department of Biology, Arizona State University, Tempe, AZ.

Russo SE, Davies SJ, King DA And TAN S. 2005. Soilrelated performance variation and distributions of tree species in a Bornean rain forest. J Ecol 93: 879-889.

SIEGEL S. 1975. Estatística não paramétrica para ciência do comportamento, Rio de Janeiro: McGraw-Hill.

SILVA FC AND SoARES-SILVA LH. 2000. Arboreal flora of the Godoy Forest State Park, Londrina, PR, Brazil. Edinb J Bot 57: 107-120.

SoARes-Silva LH AND BARroso GM. 1992. Fitossociologia do estrato arbóreo da floresta na porção norte do Parque Estadual Mata dos Godoy, Londrina, PR, Brasil. In: Congresso da Sociedade Botânica de SÃo PAulo, 8, Campinas. Anais do VIII Congresso da Sociedade Botânica de São Paulo, Campinas, p. 101-112.

Soares-Silva LH, Bianchini E, Fonseca EP, Dias MC, MEdri ME AND ZANGARO-Filho W. 1992. Composição florística e fitossociologia do componente arbóreo das florestas ciliares da bacia do rio Tibagi. 1 . Fazenda Doralice - Ibiporã, PR. Rev Inst Flor 4: 199206.

SoAres-Silva LH, KitA KK AND Silva FC. 1998. Fitossociologia de um trecho de floresta de galeria no Parque Estadual Mata dos Godoy, Londrina, PR, Brasil. Bol Herb Ezechias Paulo Heringer 3: 46-62.

SVENNING JC. 1999. Microhabitat specialization in a species-rich palm community in Amazonian Ecuador. J Ecol 87: $55-65$.

SWAINE MD AND WhitMORE TC. 1988. On the definition of ecological species groups in tropical rain forests. Vegetatio 75: $81-86$.

TSUJino R AND Yumoto T. 2007. Spatial distribution patterns of trees at different life stages in a warm temperate forest. J Plant Res 120: 687-695.

Wright SJ, Muller-Landau HC, CONDit R AND HubBELL SP. 2003. Gap-dependent recruitment, realized vital rates, and size distributions of tropical trees. Ecology 84: 3174-3185. 